\title{
Tabloid Brand Medicine Chests: Selling Health and Hygiene for the British Tropical Colonies
}

\author{
RYAN JOHNSON \\ Wellcome Unit for the History of Medicine, University of Oxford, UK
}

\begin{abstract}
During the late Victorian and early Edwardian period a surge of commodities went on display and were advertised throughout the empire. One such commodity was the Burroughs Wellcome \& Co. $(B W C)$ Tabloid brand medicine chest. The marketing of the chest was intimately related to BWC's economic and political interests in empire, contributing to a discourse of tropicality and belief in western progress and white European superiority in Britain's tropical colonies. BWC used their scientific and medical authority to further differentiate and fix western culture and the identity of white Europeans, in opposition to the tropics and their inhabitants. Despite BWC's claims to the medical and scientific superiority of these chests, the majority of their contents were in use for hundreds, if not thousands of years, often deriving from the very contexts white Europeans were supposedly civilising with their aid. BWC's advertisement and promotion of their chests, in this case, reveals processes of hybridisation between supposedly distinct cultures. The selling of Tabloid brand medicine chests contributed to a belief in western and white European superiority, but closer investigation of their contents demonstrates how such claims were, in the end, inherently problematic and unstable. Such an analysis shows that the ultimate medical value of the chests did not derive from unbiased and empirical processes, but from academic, state and industrial authority in relation to Britain's imperial ambitions.
\end{abstract}

KEY WoRDS: Tropical medicine, cultural imperialism, advertising, hybridization, pharmaceuticals

\section{Introduction}

A 1912 promotional pamphlet printed by Burroughs Wellcome \& Co. (BWC), titled The Application of Science to Industry: Souvenir of the Congress of the Universities of the Empire (1912, p. 27), stated that:

Science and Industry has been the guiding motto of B.W. \& Co. from the first ... By keeping abreast of research work and by promptly adopting the most scientific modern methods they have not only kept pace with the latest developments in

Correspondence Address: Ryan Johnson, Wellcome Unit for the History of Medicine, University of Oxford, 45-47 Banbury Road, Oxford OX2 6PE, UK. Email: ryan.johnson@sant.ox.ac.uk 
medicine and pharmacy but have been pioneers in the introduction of the most notable agents employed in modern medicine, and have contributed largely to the great advances of the times.

BWC considered one of these great advances to be 'medicine chests ... for military and naval purposes, for explorers, missionaries, travelling journalists, war correspondents, aeronauts, motorists, yachtsmen, planters; in fact, equipments for the air, for the earth, for the depths, and for every clime under every condition' (BWC, 1912, p. 43).

While this statement unambiguously indicates that they marketed their medicine chests for all adventure travel, one location stood out in particular. According to Henry Wellcome (1853-1936), from its very onset, his pharmaceutical firm 'made a special feature' of studying medical and surgical requirements for expeditions to tropical climates. This was particularly the case after Secretary of State for the Colonies Joseph Chamberlain had 'taught the nation to think Imperially' to defend Britain's economic and political interests in tropical Africa (BWC, 1912, p. 29).

In this paper I wish to consider how Tabloid brand medicine chests (BWC's patented name for their compressed tablets) were represented through advertisement and promotion in Britain, and the role this marketing played in supporting claims of western scientific and white European superiority in the British tropical colonies (Adas, 1989; Meade \& Walker, 1991; MacLeod, 2000; Drayton, 2000).

Medicine chests in late nineteenth and early twentieth century Britain were by no means novel commodities; however, BWC improved upon larger and bulkier versions because their Tabloid pills reduced the size and amount of therapeutics to transport. Although this made them lighter and easier to haul, they housed similar patent medicines, dressings and basic surgical equipment to those found in earlier models. To promote the novelty of the Tabloid pills in their chests, BWC advertising sections in journals such as Tropical Life, Medical Missionary, Journal of Tropical Medicine, and Climate, were dominated by full-page adverts. Instead of simply displaying the chests, like many of their competitors, BWC placed them in tropical contexts, actively used, or carried by local porters 'on the march' (Figure 1). In their advertisements, BWC

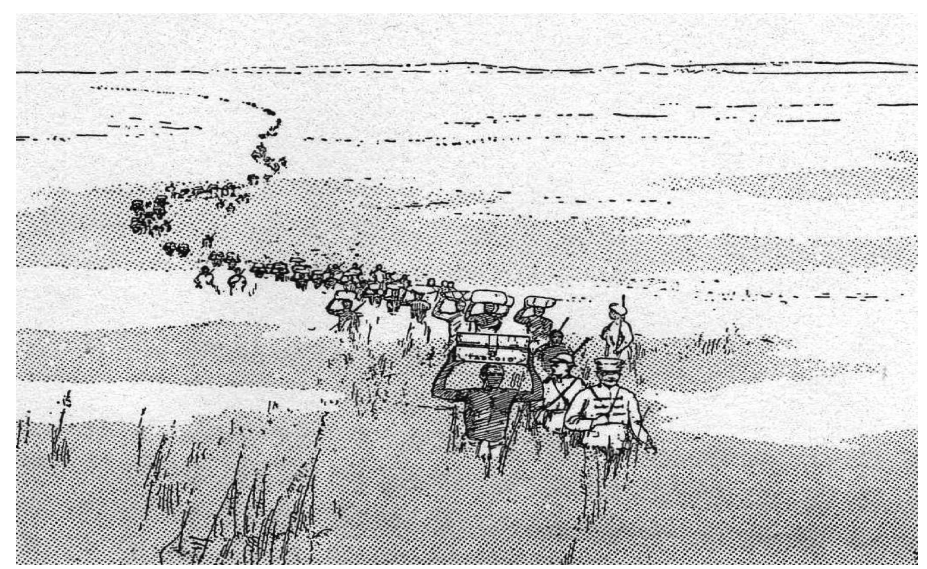

Figure 1. "Tabloid" medical equipments in Central Africa'. Source: BWC, A Brief History of Missionary Enterprise (London, 1912, p. 272). 
carefully positioned the chests to demonstrate their practicality and ease in providing basic medical care in remote places, but beneath such marketing was a belief in the inevitable progress and superiority of western science and culture over local practice and systems of knowledge.

Despite BWC's claims to western scientific and white European superiority embodied in the medicine chests, this paper also demonstrates how such claims were, in the final analysis, belied by the composition of the Tabloid pills they contained. Nonetheless, taken as a whole commodity, the chests were marketed by BWC as modern and scientific, not partly modern, or somewhat scientific. An important question to ask, therefore, is why did BWC aggressively promote and advertise their chests as being on the vanguard of modern medical science?

BWC had their own specific interests in relation to empire, demonstrating that there were multiple, sometimes oppositional colonial discourses (Lester, 2006). Properly equipped with the most modern and scientific medical equipment, BWC helped convince middle class British men and women to undertake a journey that was notoriously fatal, even if by the early twentieth century this was no longer entirely true (Curtin, 1989). When the contents of the chest are analysed, however, it is difficult to maintain the argument that they were composed of anything truly on the cutting edge of medical science, revealing ongoing processes of hybridization between supposedly distinct cultures. Before investigating this and the contents and marketing of the chests further, it is first helpful to situate them within the larger context of late Victorian Britain and its emerging commodity and advertising culture.

\section{Selling Tropical Health and Hygiene: Late Victorian Commodity Spectacle and Advertising}

According to Thomas Richards, between the Great Exhibition and the Great War, the commodity in Victorian culture was transformed from a fairly 'trivial' thing, into 'the centerpiece of everyday life, the focal point of all representation, the dead center of the modern world' (Richards, 1990, p. 1). Though Richards' pervasiveness of the commodity might be overstated, its position in British life had changed dramatically over the course of the nineteenth century. A system of representation emerged animating the commodity through spectacular displays informed by ideologies of capitalism, England, and empire. Inspired by the Great Exhibition, smaller ones proliferated with a concomitant and diffuse rise in advertising. ${ }^{1}$

Richards argues that images surfaced around commodities through exhibition and advertising reflecting the desires and anxieties of a new breed of middle class consumer. By all accounts, late nineteenth century Britain appeared to be drowning in a sea of prosperity indexed by the endless variety of commodities advertised and on display at exhibitions throughout the empire. Far from the realities of poverty and bare working class living rooms, a myth of surplus gathered around representations of wealth and abundance, legitimizing and consolidating support and the need for imperial expansion (Richards, 1990, p. 121).

Images of Africa and Asia figured prominently in upholding the importance of the commodity, its relationship to capitalism, securing overseas markets, and as a source of civilization. Jan Nederveen Pieterse (1992, p. 188) notes that, 'As non-western areas were integrated politically under imperialism, and economically through the international division of labour, the cultural incorporation of the non-western world took form in western 


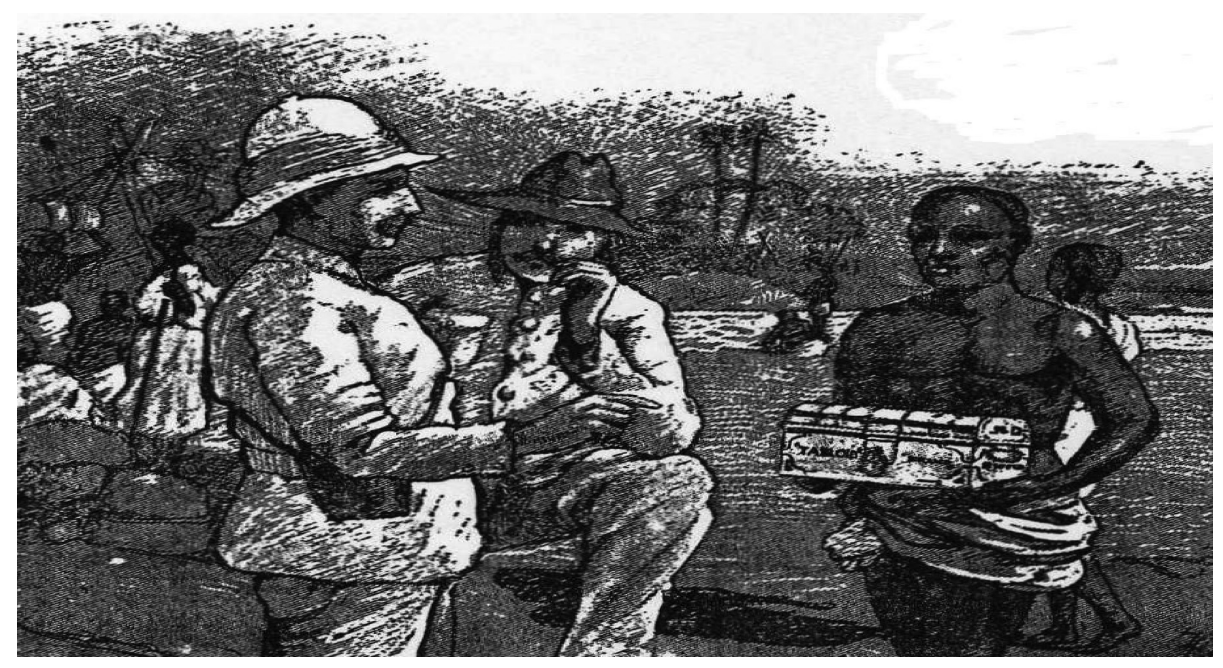

Figure 2. 'Tabloid' advertisement 1900. Source: Advertisement column, Climate, 2(5), (1900), p. i.

exoticism'. Stereotypes and racial images were frequently employed by companies advertising such commodities as soap, tea, and tobacco, as well as pharmaceuticals, clothing and other commodities for the preservation of health in tropical climates. Labouring local porters hauling chests alongside refined Europeans in distinctive tropical garb, for instance, were frequently employed by BWC (Figure 2).

According to Anne McClintock (1995, p. 209), 'Victorian advertising took explicit shape around the reinvention of racial difference. Commodity "kitsch" made possible, as never before, the mass marketing of empire as an organized system of images and attitudes'. In this context, scientific racism was packaged, marketed and sold through a variety of goods, especially commodities purporting to preserve white European bodies against the vagaries of a highly racialized tropical climate.

The marketing of commodities in this manner also upheld the western belief in a hierarchy of civilizations, with the west-particularly Britain-at the summit. From at least the late eighteenth and early nineteenth century, Europeans increasingly adhered to certain transcendent truths about the physical world. Such 'truth' existed independent of human agency, and was equally valid for all people. According to Adas (1989, p. 6), Europeans felt they had 'better understood these truths or had probed more deeply into the patterns of the natural world which manifested the underlying reality'. Through the elucidation of such transcendent truths_-aided primarily by science-western civilization was considered at the pinnacle of a natural progression that all human societies and cultures were moving along. It was the west's responsibility, therefore, to assist the transition of less advanced societies and cultures through the various stages they had already successfully navigated.

The commodity, especially, was considered essential in this process. Looking specifically at soap, McClintock (1995, p. 223) argues that its advertisement in the late nineteenth and early twentieth century, 'embodied the hope that the commodity alone ... could convert other cultures to "civilization"'. Looking in depth at Henry Morton Stanley's (1841-1904) travel narratives in Africa, Richards (1990, p. 123) demonstrates Stanley's 
belief that civilizing Africans would be possible through teaching them the value of commodities. Such was his conviction that he went as far as executing three of his porters for stealing rifles.

Throughout Richards' and McClintock's analysis, the use of racial imagery in late Victorian and early Edwardian advertising figures prominently. Anandi Ramamurthy (2003), however, criticizes both McClintock and Richards for failing to bring together the particular political and economic interests of individual companies in relation to their specific use of racial imagery. Expanding on McClintock's and Richards' research, Ramamurthy finds fault in their overly textual analysis at the expense of historical and economic contextualization; and their failure to link the analysis of representations of Africa and Asia to the production of goods they are associated with. To understand the origins, meanings and symbolism of such advertising requires placing it firmly within the idiomatic economic, political, and cultural contexts giving rise to it. Tropical imagery and representations of Africa and Asia, Ramamurthy (2003, p. 9) notes, 'were employed strategically in advertising to represent company interests in specific colonial ideologies and policies'. To fully appreciate how and why the chests were advertised by BWC we must consider them within the political and economic context of the 'new' imperialism and 'scramble for Africa', wrought out of changes in European politics and developments in the periphery. ${ }^{2}$

\section{The Consummation of a Secret Wish: Exploration, Empire and Tabloid Brand Medicine Chests}

Stretching across the empire, and looking to establish an ever increasing number of research and manufacturing facilities, BWC had an explicit economic and political interest in maintaining and promoting British imperialism. Joseph Chamberlain's policy of 'constructive imperialism' provided the stimulus for the research and eradication of tropical diseases, and in large part gave rise to the London and Liverpool schools of tropical medicine (Wilkinson \& Hardy, 1998; Power, 1999). Related to this work, BWC conducted research throughout the empire in its own laboratories, and in conjunction with state and colonial facilities (D'Arcy, 1999; Church \& Tansey, 2007). They were active in developing new products and supplied medical equipment, or at least significant discounts, to the Colonial Service and other state agencies. While BWC, like any good capitalist company, generally stayed clear of interfering in the administration and management of the tropical colonies, they helped foster an appeal to the expansion of empire. They also facilitated the recruitment of men and women not so much interested in wealth, but civilizing the 'other', with at least the promise of adventure.

Born in Almond, Wisconsin, USA in 1853, Wellcome partnered with college friend Silas Burroughs (1846-1895) in 1880. Through connections made as pharmaceutical salesmen, they eventually established in London what would become one of the largest pharmaceutical firms in the world. Legend has it, while meeting with Stanley sometime in the 1880s, Wellcome, a fellow explorer and man of adventure, derived the inspiration to launch a medicine chest department within his burgeoning medical supply and pharmaceutical firm. ${ }^{3}$

Tabloid brand pills were the cornerstone of the business, allowing Wellcome to carve out a large niche in the relatively uncompetitive manufacture of pharmaceuticals in London. However, according to one of his own promotional pamphlets, Wellcome did not conceive 
of the original concept of the Tabloid, admitting, 'Burroughs Wellcome \& Co. are successors to, and the sole proprietors of, the business of BROKEDON, who, in 1842, originated compressed medicines in the shape of bi-concave discs-issued under the designation of "compressed pills"'(BWC, 1910, pp. 259-261). It was Wellcome, though, who brought the production of the pills to 'a high state of perfection' with 'exclusive machinery, invented and patented by the firm, and produced at a great cost' (BWC, 1910, pp. 259-261).

The manufacturing process Wellcome created was novel, not the pills themselves. Nonetheless, he still faced difficulties from imitators and sought a name for his new system. He felt 'Equivalents' might be good; he then pondered 'Equaloids', 'Equoids' or 'Equivaloids', but none were to his satisfaction. Torn between two names, he registered both 'Valoid' and 'Tabloid' on 14 March 1884 (James, 1994, p. 113).

The word that eventually entered English parlance was a mixture of 'tablet' and 'ovoids', giving his compressed medicines a unique and patented name. BWC hailed themselves as 'having completely revolutionised the methods of administering medicines by the introduction of their "Tabloid" system' (BWC, 1896, p. 119). The pills helped establish BWC as a household name, while also making Wellcome's medicine chests an international sensation, and the very embodiment of exploration, travel, and adventure.

The advertisement shown in Figure 3 emphasizes medicine chests as essential instruments within polar, temperate and torrid zones. BWC linked the chests with both adventure and danger, making them sign and signifier of imperial spirit. The carefully crafted

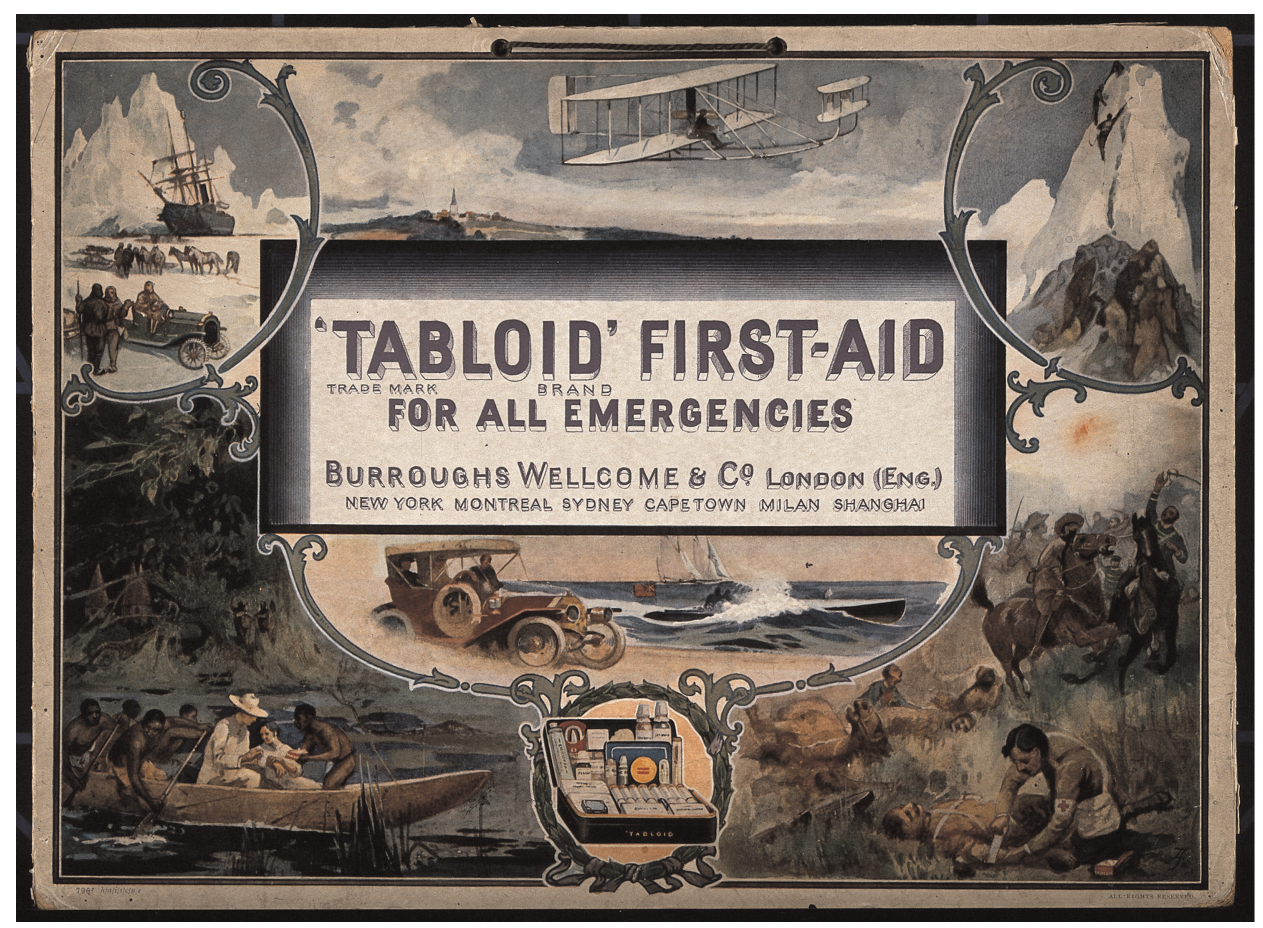

Figure 3. 'Tabloid: first-aid for all emergencies', 1908. Source: Wellcome Library, London. 
and marketed chest denotes the need for medical care in remote places, but the advertisement's connotations run much deeper. The chests were folded into the entire experience of empire, being firmly placed within iconic images of exploration and adventure. Whether you were valiantly saving your compatriot in war, traversing a dark African jungle, navigating one of the world's first flying machines, exploring the most desolate place on earth, ascending the highest mountain in the world, or, simply enjoying the wind swept British coast, the chest would be there, ready for any ailment.

The advertisement also suggests the place of the tropics in relation to temperate and polar landscapes. The automobile in the centre represents civilization between the extremes of heavenly flight, mountain ascent, hellish warfare and swampy, torrid jungle. Such clever advertising by BWC was perhaps more important than the novelty of the pills and chests themselves. The success of the chests hinged on their being coupled to famous adventures, pandering to a nation obsessed with empire and exploration (Driver, 2001). Wellcome was personally acquainted with many explorers, most notably Stanley. Advertisements and promotional pamphlets for the chests were filled with testimonials from prominent explorers, military men, missionaries, and physicians. BWC (1910, p. 271) proudly noted that, 'In his books, Founding the Congo Free State and In Darkest Africa, the late Sir H.M. Stanley wrote in the very highest terms of "Tabloid" Medical Equipments'.

Throughout Britain, the chests eventually became as famous as the explorers who used them, going on tour, with their own history and stories of adventure: for instance, when a Tabloid chest furnished to Emin Pasha was lost in an Arab slave raid, recaptured by Baron Dhanis, Commandant of the Congo Free State Troops, stolen again, and then somehow recovered near Kenia 'dwarf' country, in tact, and Tabloids unspoilt (BWC, c.1925, p. 11). Another 'famous medicine chest, used during Stanley's travels, has an interesting history. This was his "Rear-Guard" "Tabloid" medical chest, which for nearly four years was left in the swampy regions of Aruwhimi', and 'more than once, it was actually under water ... Its remaining contents were tested by the official analyst of the Lancet . . . one of the leading British medical papers, who reported the "Tabloid" Medicaments were in a perfect state of preservation' (BWC, 1934, p. 27). Stanley's lionized 'Congo' chest (Figure 4), celebrated in BWC advertisements, eventually became the mass produced No. 250, and the most popular with 'every important tropical exploring, military or missionary enterprise' (BWC, c.1925, p. 30).

Chest No. 250, from the 1890 s up to the 1920 s, contained six 5 oz. and $303 \frac{1}{2}$ oz stoppered bottles of Tabloid and Soloid brand medicine composed of some of the following treatments: cascara sagrada for 'sluggish liver'; iron and arsenic for convalescence during malarial fevers; calomel as purgative, cathartic and liver stimulant; lead and opium for severe diarrhoea; Warburg's Tincture for malaria and other fevers; ipecacuanha powder for gastric irritation, general expectorant, and emetic for poisoning; quinine, calomel and rhubarb (Livingston Rouser) as cathartic, tonic and anti-malarial, and especially adapted for use as a purgative in the tropics; large amounts of quinine bisulphate for anti-malarial tonics; Dover Powder for pain relief; sulphonal for sleeplessness; ginger essence for aromatic stimulant; Easton Syrup as an excellent restorative tonic; ammonium chloride for sore throat and 'torpid' conditions of the liver; and soda mint for general nausea, dyspepsia and the occasional case of flatulence. ${ }^{4}$

The chest also contained suture needles, suture silk, oiled silk, mustard leaves, adhesive and court plaster, caustic point, a yard of lint, catheter, glass syringes, medicine droppers, 


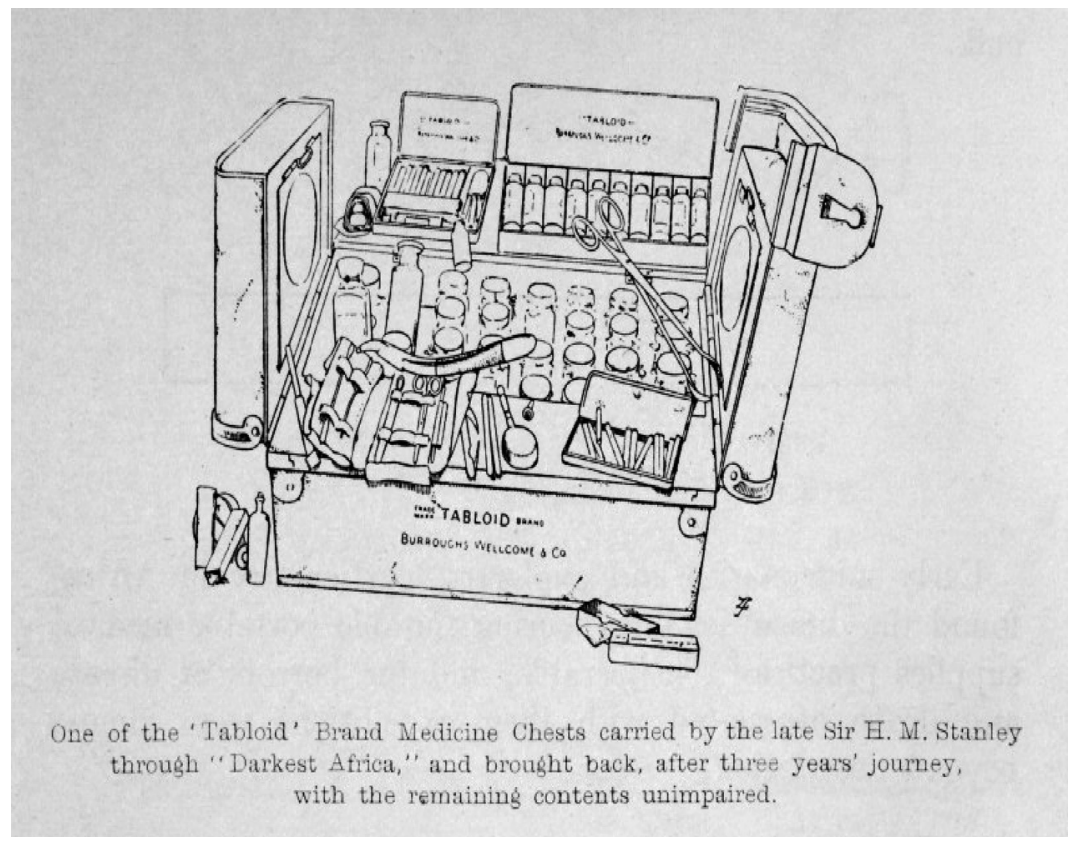

Figure 4. Stanley's 'Congo' chest. Source: BWC, 'Tabloid’ (London, c.1925, p. 30).

clinical thermometer, scissors, lanolin and a lancet. The chest weighed about $40 \mathrm{lbs}$, and whilst a substantial improvement over previous methods was still a considerable weight.

If no local porters were to be found, or if a personal chest was desired, the 'Indian medicine chest' —or No. 254-was a favourite choice, especially amongst missionaries. The 'Indian' had the advantage of light weight (about $12 \mathrm{lbs}$ ), and could be kept close to a European body. It was made of teakwood, so it was 'not easily attacked by white ants', and lined with 'japanned' metal to keep the contents safe from the tropical elements (Figure 5).

The chest had the usual accoutrements, except in fewer amounts. It contained $161 \frac{3}{4} \mathrm{oz}$ glass stoppered bottles, six four dram phials, and lacked bulky items such as $7 \mathrm{lbs}$ of Vaseline, $10 \mathrm{lbs}$ of Epsom salt, and $10 \mathrm{lbs}$ of boric acid. Missionaries from Livingstone College referred to the chest as the 'Livingstone College Medicine Chest', and adored it as much they might a college mascot (Battersby, 1900, pp. 26-27). Amongst foreign missionaries, and medical missionaries, the chest was as famous as the iconic No. 250.

The chests were meant for any number of injuries or ailments in all types of climates; however, according to BWC (1934, p. 7), 'A danger far worse than that of broken limbs, of cuts and gun-shot wounds, hangs over the traveller in remote places, particularly in the Tropics. The worst menace he has to face is disease'. To combat this 'menace', BWC (1934, p. 8) noted how earlier travellers and explorers arrived equipped with little more than quinine, castor oil, and possibly some bandages; and if other drugs were taken, they were soon useless, 'because they deteriorated so rapidly in hot climates; or else they were so bulky that it was impossible to carry them through thousands of miles of tropic jungle'.

Tabloid brand medicine chests were sold as having solved these problems, and 'in the penetration of Africa, "Tabloid" Medical Equipments have made the way of the explorer 


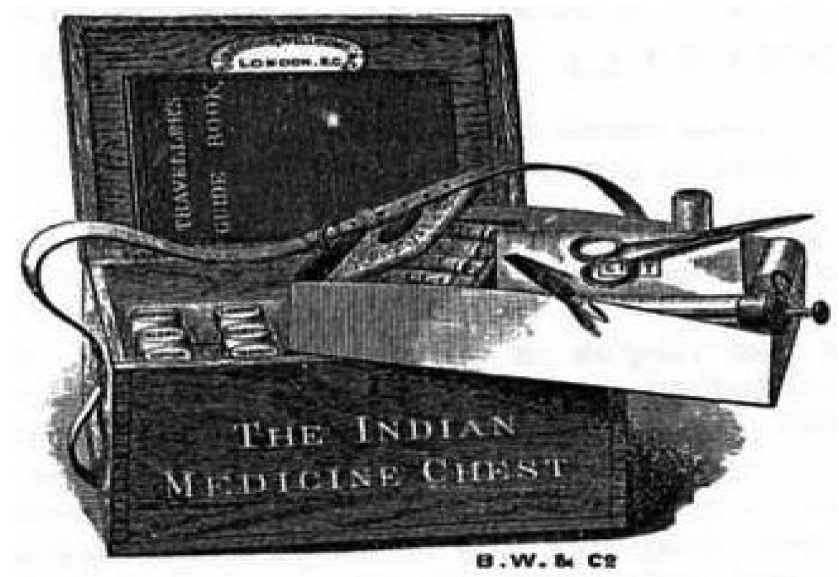

Figure 5. The 'Indian' medicine chest No. 254. Source: Charles Harford-Battersby, 'Medicine chests', Climate 2(5), (1900), p. 26.

and pioneer infinitely less perilous. There were no roads, the climate was deadly, and everything had to be carried pack fashion on the human head and shoulders' (BWC, 1934, p. 8). With the advent of the chests, 'a single porter could carry medical supplies sufficient for a regiment of men. By their aid the European explorer was enabled to traverse deadly swamp and fever ridden forest in safety' (BWC, 1934, p. 8). Stanley recalled, 'the dreadful mortality ... and sickness due to the crude way in which medicines were supplied to travellers. The very recollection causes me to shudder' (BWC, 1934, p. 9). Stanley's problems were solved, however, at the famous meeting, where he made 'the acquaintance of Messrs. Burroughs Wellcome \& Co' (BWC, 1934, p. 9). After their encounter, Stanley found 'the consummation of my secret wish. On my later expeditions I had all the medicines that were required for my black men, as well as my white men, beautifully prepared, and in most elegant fashion arranged in the smallest chest it was ever my lot to carry into Africa' (BWC, 1934, p. 9).

\section{'Hand and Hand with the Advance of Civilization': Imagining the Use of Tabloid Brand Medicine Chests}

Historian Daniel Headrick (1981) has attributed the penetration of Africa-and the entire colonial project in the late nineteenth century-to the development of technologies that coincided with the 'new' imperialism. He argues that European imperialists now had both the means and the motivation to pursue aggressive formal colonization, especially in Africa. Quinine, for instance, coupled to other advances, allowed Europeans to push further and deeper into tropical Africa, opening it up for exploitation. Headrick (1981, p. 72) states, 'Scientific cinchona production was an imperial technology par excellance. Without it European colonialism would have been impossible in Africa, and much costlier elsewhere in the tropics'.

While the effective production of large amounts of quinine might have facilitated further exploration, statements which claim that such technologies, coupled to the politics of a 'new' imperialism, were a primary reason for the eventual colonization of tropical 
Africa are rather grandiose. Prior to such developments, a great loss of African and European life went into erecting basic infrastructures of transportation, housing and sanitation. Africa, well before Stanley and Livingstone treaded through the Congo, was not so remote and untouched by previous European encounters (Brantlinger, 1985). It was imagined as a wild and unknown space, even though maps from the early modern period provide detailed knowledge of African geography, while eighteenth century accounts of voyages show intimate details of African peoples. Nicholas Mirzoeff (1999, pp. 129-161) argues that in the mid and late nineteenth century Europeans disregarded this knowledge and created in its place the myth of the 'dark continent' - the European reinvention of Africa as a primitive wilderness. Utilizing and reinforcing this myth, BWC marketed their chests as indispensable tools within the 'primitive wildernesses' of Africa, even though few who ever purchased the chests would travel to such imagined and remote places.

The manner in which BWC advertised and promoted the chests also contributed to what historian David Arnold (1996, 2000) has termed a discourse of tropicality. Drawing on the work of Edward Said (1979), he notes how the tropics were understood as a specific geographical location extending from the equator to the North and South parallels of the tropic of Cancer and Capricorn; however, they were also a conceptual space-something culturally and politically alien, as well as environmentally distinctive from the west. Throughout western discourse the tropics have been subject to a duality - a tropical alterity —of paradisiacal and pestilential, the site of luxuriant excess alongside primitiveness, violence and destruction. Western language describing tropical climates was saturated with words such as paradise, plush, and bountiful, alongside danger, disease and darkness. ${ }^{5}$

BWC actively promoted this imagery of the tropics, portraying their chests as the ideal antidote against a tropical landscape at once full of potential wealth for imperial Britain, but simultaneously rife with disease. BWC $(1934$, p. 8) claimed the tropical colonies 'are by far the most dangerous regions for travellers', where 'desolating ailments' are encountered, all of which 'are particularly fatal to the so-called white man who originates in temperate climates'. ${ }^{6}$ BWC sold their Tabloid brand medicine chests as 'weapons of precision' in such abundant, yet dangerous spaces (BWC, 1912, p. 29). A scientist studying gorillas in the West African forests of Gabon, for instance, found his Tabloid brand medicine chest, 'A treasure more sacred than my rifle' (BWC, c.1925, p. 30).

Despite such claims, many effective treatments - such as quinine, opium and a basic first aid kit—were easily carried and utilized well before the appearance of Tabloid brand medicine chests (Young, 1994). While the going was certainly tough, a small medicine chest with a majority of tablets whose effectiveness was at best uncertain, would probably not have improved the preservation of health in tropical climates to any great degree. Perhaps the only lives that did improve were those of local porters, who, instead of having to carry heavier and bulkier medical supplies, might be lucky enough to haul just a single, lighter, chest. Though, ironically, since European colonialism often brought or intensified disease, the porters were more than likely suffering from ailments the chests they were hauling were meant to relieve (Lyons, 1992; Feierman \& Janzen, 1992).

We should also question our superimposing of western advancement-whether it be roads, sanitation, housing, quinine, or medicine chests-to explain the extension of European life in tropical Africa. It might just be that increasing contacts with local people facilitated relationships that allowed Europeans access to better conditions of health already in place; and Tabloid brand medicine chests-as an exchange 


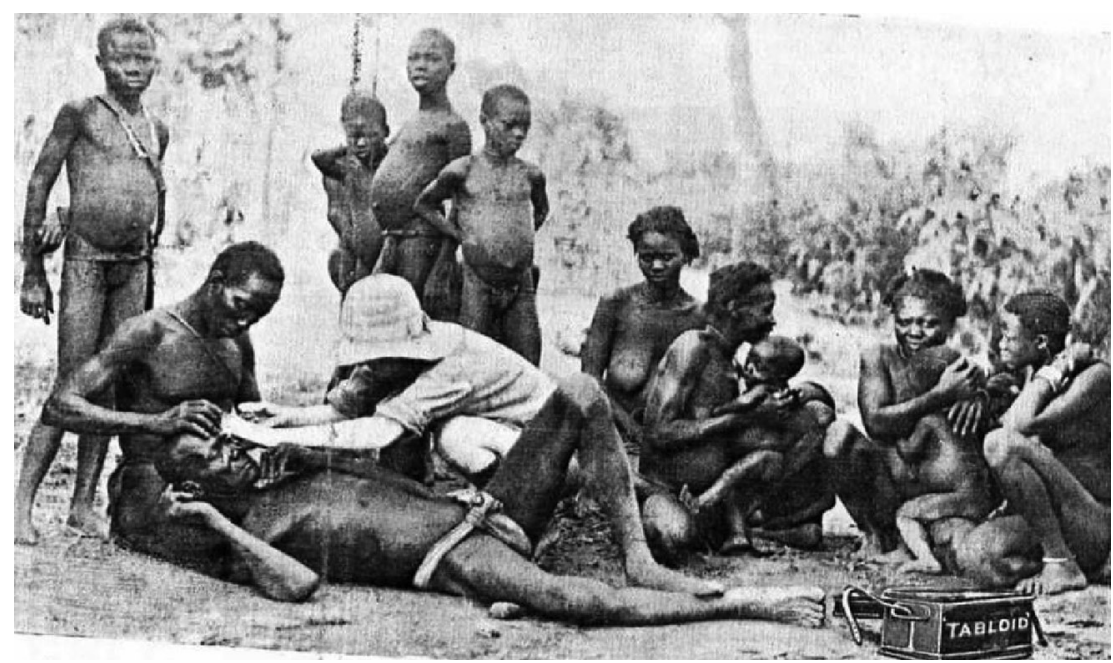

Figure 6. 'Mauled by a leopard'. An African Chief, receiving treatment from Mrs Glover, wife of Mr T. A. Glover, leader of the 'Glover expedition to Tibetsi'. Source: BWC, The Romance of Exploration (London, 1934, p. 16).

commodity-might have been useful in this respect rather than contributing directly to the improvement of health (Hill, 2006, pp. 373-376). Nonetheless, western medical intervention was often portrayed as an important first contact between Europeans and locals, with Tabloid brand medicine chests pictured next to missionaries and practitioners applying western medicine to local bodies (Figure 6).

The chest in Figure 6 is similar, if not an actual depiction of the 'Indian' medicine chest. However, it has been doctored by BWC — if not simply added to the photograph—emphasizing its role, and western medicine, in the abatement of local suffering. The possibility it might not have ever been in the picture is telling. The chest becomes an imagined artefact of experience in the tropics, with BWC asking the viewer to see it as an essential element in the interaction between Europeans and locals. It becomes a piece of equipment, along with the sola topi worn by Mrs Glover, representing the authority and superiority of western civilization and scientific medicine next to the naked backwardness of local culture.

In the photo, Mrs Glover kneels in stark contrast to the local men and women, she is displayed showing the self sacrifice and caring qualities needed by the European 'civilizer' for the expansion of empire, with the imaginary medicine chest conveniently by her side. Because the medium of artistic representation is easier to control, Harold Copping's 1916 oil painting, The Healer (Figure 7), is perhaps even more emblematic of this 'imaginative geography' and material expression in Tabloid brand medicine chests (Ryan, 1997; Stepan, 2001).

Copping was known throughout Britain for his painting of missionary work, and The Healer portrays a missionary attending a young boy suffering, with Christ standing over the missionary's shoulder emanating light in approving benevolence. Next to the missionary is a medicine chest that looks very similar, once again, to the No. 254. Bandages are strewn about, and a man standing with an arm sheathed-in what must be 


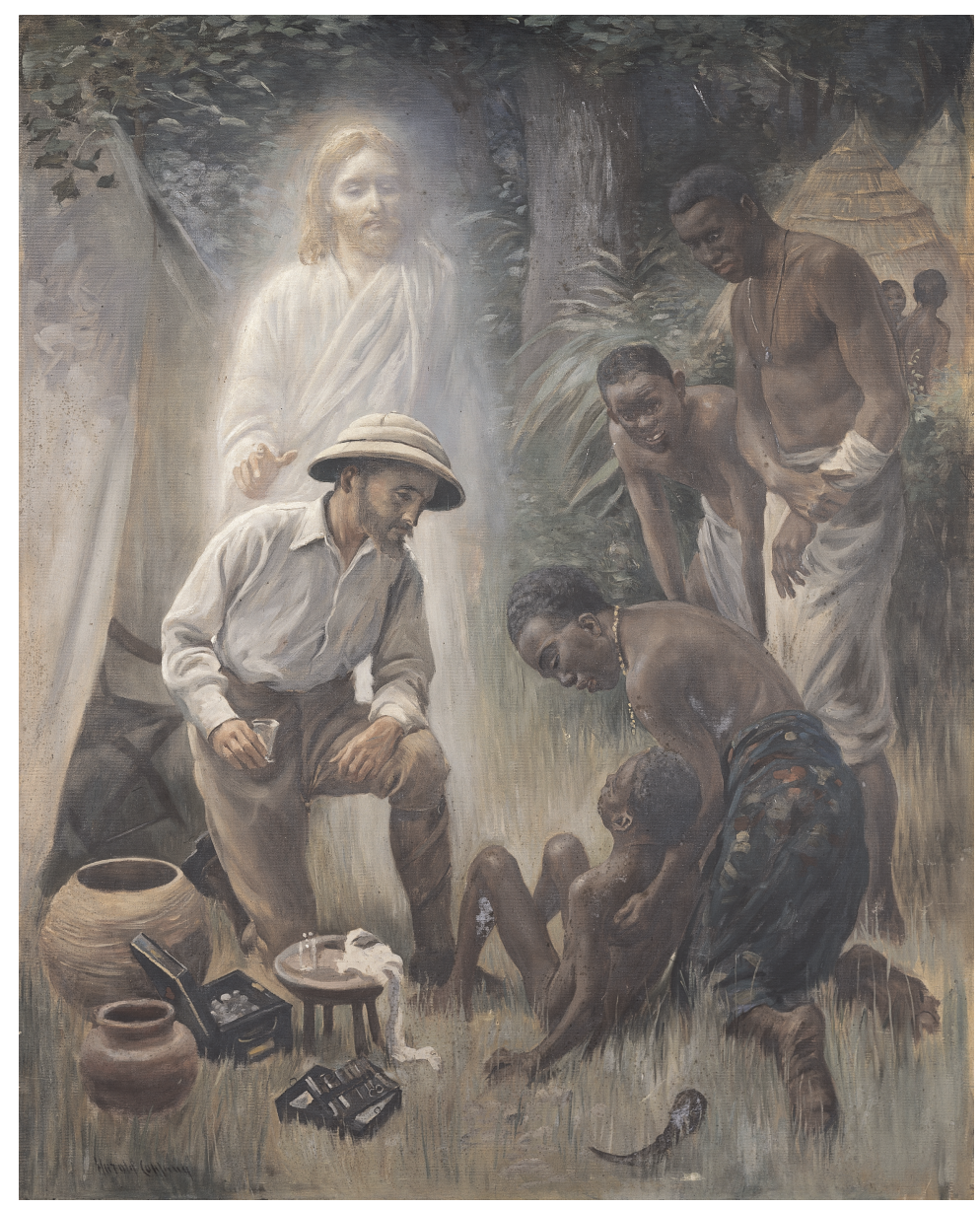

Figure 7. The Healer, oil painting by Harold Copping, 1916. Source: Wellcome Library, London.

western gauze-looks on intensely, suggesting an accident has occurred. Thrown to the side in the painting, as if in utter uselessness, is a local cupping horn. Cupping horns are advanced forms of African and Asian medical technology in both theory and practice. They are hollow antelope or goat horns with a small hole at the tip, usually stoppered with a piece of wax. The horns are heated and placed on the skin, removing the wax, creating a suction, or 'cupping' effect, which is thought to relieve the afflicted area and restore balance.

The discarded horn, the prostate men looking on and the woman holding the injured boy, in opposition to the missionary, Christ, and the medicine chest, are undoubtedly gestures to the assumed racial and moral superiority of western civilization and medicine over local practice and culture. According to BWC (1934, p. 29),

'[T]abloid' medical equipments have been the choice of famous missionaries and of the foremost missionary organisations throughout the world, because it is recognised 
that not only do they enable effective medical treatment to be given in the most remote places but they are a valuable asset in securing the attention and goodwill of the natives to religious teaching.

BWC (1934, p. 29) further note that the Tabloid brand medicine chest went "hand in hand with the advance of civilisation, the conquest against disease and the battle against ignorance and superstition'. As such, the chests were considered part of the civilizing mission. Pictured alongside white Europeans, BWC promoted them as scientific medical practice in remote regions, signifying western progress against local 'ignorance and superstition', even though they remained virtually unchanged for over 30 years.

\section{Old Pills, New Packaging: Hybridization and Tabloid Brand Medicine Chests}

Despite BWC's claims to the medical and scientific superiority of the chests, the majority of their contents were far from modern and scientific remedies. Tabloids that contained cinchona, ipecacuanah, cascara sagrada, calomel, or patent medicines such as Warburg Tincture, Dover Powder and Easton Syrup, were either derived from outside Europe, or had been in use for decades, if not centuries. The only aspect truly western and modern about the chests was their mass production, and expertly honed marketing.

It was not a tightly guarded secret that local plants and remedies were regularly refashioned into acceptable western medications. BWC did not hide the fact they frequently found inspiration from local practice. They triumphantly acknowledged how certain drugs were developed through observing locals, and that the real benefits of such remedies were only truly discovered when they had been recast through western science.

One example is that of the Strophanthus plant, found primarily in Africa and Asia, belonging to the same family as digitalis. BWC (1912, p. 29) state, 'The firm has pioneered the introduction of many new and valuable natural drugs, notable amongst which may be mentioned Strophanthus, or Kombé, the powerful African arrow poison which has proved so useful in certain heart disorders'. The plant contains a chemical agent in the fluid of its seeds that influences circulation. The drug was 'discovered' after, 'Sir Thomas Fraser, of the Edinburgh University, first investigated and demonstrated, in 1885, the properties of Kombé", with BWC taking immediate and "vigorous steps to procure supplies of the drug regardless of expense and immense difficulties' (BWC, 1912, p. 31). The seeds were gathered by, 'Emissaries ... sent to collect the small reserves of arrow poison from the rude huts of many Central African warriors', whereby, 'the true Strophanthus Kombé was first introduced to England and to the world' (BWC, 1912, p. 31).

According to BWC (c.1925, p. 26), for 'tropical countries generally, the following selection of medicines may be suggested on account of their all around usefulness': cascara sagrada, ipecacuanha, opium and lead, quinine, Dover Powder, Easton Syrup, and Livingstone Rouser. Looking at the origin of many of these remedies is revealing. Cascara sagrada, a mild laxative, derives from the bark of the North American buckthorn tree and has been utilized by Native Americans and Europeans for at least 1000 years. Quinine derives from the bark of the South American cinchona tree. Ipecacuanha, a powerful emetic, is a native plant species of Brazil, introduced to Europe in the seventeenth century; and Dover Powder is simply ipecacuanha with opium. 
Other popular patent medicines, such as Easton Syrup, contained strychnine and quinine, while Livingstone Rouser contained quinine, calomel and rhubarb. Opium was never in short supply, with the Tabloids opium and lead, and aromatic chalk powder and opium, present in copious amounts in both the No. 250 and No. 254 medicine chests. In fact, as Johannes Fabian (2000, pp. 63-75) has argued in his book, Out of Our Minds: Reason and Madness in the Exploration of Central Africa, most travellers distrusted many of the medicines they brought with them, except for, of course, opium and alcohol.

From this brief overview of the composition and origin of some of the more important Tabloids for tropical travel, it is obvious they were not the sole genesis of western ingenuity. Despite this, the chests were advertised by BWC as containing the most modern and scientific remedies western medicine had to offer. BWC repeatedly thrust forward their chests as anxious representations of western science and medicine, attempting to fix the identity of locals as superstitious and backwards by promoting the chests in a manner similar to the colonizer aggressively asserting his or her own superiority. The medicaments were characterized by 'purity, accuracy, uniformity and reliability', and overall 'supreme quality' (BWC, 1912, p. 27). As the quote at the beginning of this paper declared, the chests were marketed as containing some of the most 'notable agents in all of modern medicine', and contributing to 'the great advances of the times' (BWC, 1912, p. 27).

A survey of the chest's contents suggests, however, that their scientific integrity and superiority-like the colonizer always anxiously contemplating his or her own identity-were never quite as stable as such aggressive promotion implied. It was BWC's constant reference to the chests and their Tabloid pills arising from western ingenuity and scientific superiority that draws out most acutely the ambivalence of such claims. Looking at the history of some the chest's contents reveals processes of hybridization that help displace and decentre power relationships and notions of knowledge diffusing from centre to periphery (MacLeod, 1987; Chambers \& Gillespie, 2000).

The Tabloid pills in BWC's medicine chests provide material form to the argument that cultures are not discrete bounded entities; rather they are constantly in contact and exchange. This does not mean Tabloid pills should be understood as arising from disparate, pre-existing cultures, coming together within the chests in a mosaic of remedies. As Homi Bhabha (1994, p. 114) asserts, 'colonial hybridity is not a problem of genealogy or identity between two different cultures which can then be resolved as an issue of cultural relativism'. Seen in the margin between the meeting point of 'colonizer' and 'colonized', the contents of the medicine chests do not simply reveal a hybrid of cultures, or bio-pirating, but an active and ongoing process of spatial and temporal hybridization between people and things constantly forging new identities. ${ }^{7}$

Despite the instability of BWC's claims emerging through the contents of the chests, their marketing contributed to the fixing and stabilizing of western culture in opposition to African and Asian culture. BWC's advertisement and promotion of Tabloid brand medicine chests, in this case, provides an example of science and medicine functioning as culture. The idea of a separate, superior western culture was given credence through BWC's scientific and medical authority voiced in numerous advertisements and promotional pamphlets. As shown above, BWC re-appropriated a number of therapeutic remedies, re-casting them through western science and medicine to further legitimize 
the notion that Britain, and the rest of western Europe, were operating at a higher stage of progress than people located in the tropical colonies.

Nonetheless, despite BWC's attempt to claim Tabloid pills as their own through western scientific and medical authority, the complex composition of the pills demonstrates how, 'Hybridity is a problematic of colonial representation and individuation that reverses the effects of the colonialist disavowal, so that other "denied" knowledges enter upon the dominant discourse and estrange the basis of its authority-its rules of recognition' (Bhabha, 1994, p. 114).

\section{Conclusion}

In summary, investigation of how and why BWC advertised and promoted their Tabloid brand medicine chests, reveals the immense energy that went into shaping and sustaining certain stereotypes in relation to Britain's tropical colonies. The chests were sold in a manner supporting a discourse of tropicality, and travellers purchasing them would have been influenced by such marketing before leaving the shores of Britain for any number of local colonial contexts. Integrating knowledge from the colonies and myths developed in the metropolis, BWC's selling of Tabloid brand medicine chests, as a whole commodity, anxiously upheld claims of western racial and scientific superiority. Such claims emerged through BWC's particular interests in advancing empire, and their value depended upon the successful adoption of stereotypes functioning in the justification of empire.

BWC specifically marketed Tabloid brand medicine chests to middle class white Britons who sought to participate in a paternalistic civilizing mission. With commercial and imperial interest spreading in many tropical contexts (Havinden \& Meredith, 1990), these men and women were perceived to be in ever increasing need. BWC played the chests off white European anxieties in relation to tropical climates, reinforcing the identity of these 'civilizers' against those of the 'savages' they would supposedly be civilizing. The chests became an extension of the belief in the colonizer as civilizer, signifying not only the blessing of Christ, but of science. As Copping's painting suggests, they provided a way to communicate and engage, bringing Europeans and locals closer together by securing their 'attention and goodwill' (BWC, 1934, p. 29).

Along with an analysis of such marketing, this paper has also shown that contrary to BWC's assertions of scientific and racial superiority embodied in the chests, investigation of their contents inform against such claims. Composed of therapeutics in use for hundreds, if not thousands of years in Europe, Africa, South America and Asia, the contents and manner in which they were marketed complicates a clear demarcation between metropolitan centre and colonial periphery-and that they were operating at different stages of a teleological driven notion of progress.

Many of the studies considered above have advanced our own understanding of how British notions of superiority and progress emerged through the mass production, marketing and consumption of certain commodities. The selling of such goods as sugar, tobacco, tea, coffee, and soap, took advantage of the belief that British culture was functioning at a higher stage of progress than 'other' cultures in the empire. In particular, Richards (1990), Pieterse (1992) and McClintock (1995) have shown how the marketing of many imperial commodities were directed towards white Europeans only. Africans and Asians were not considered consumers of such products, but their images were utilized instead to promote the assumed superiority of western culture and white Europeans. BWC advertisements 
consistently portrayed white Europeans as the primary consumers of Tabloid brand medicine chests, while naturalizing the role of Africans and Asians as labourers and servants.

However, as we have seen, the advertising of Tabloid brand medicine chests also conveyed the importance of transferring western science and civilization to 'backwards' and 'superstitious' people inhabiting the British tropical colonies. Such marketing implied that they too, someday, could become consumers and beneficiaries of such technology. Mona Domosh (2004, p. 459), for instance, has shown how the American companies Singer and McCormick, 'presented raced bodies as potential consumersubjects' in their advertisements. ${ }^{8}$

Drawing on the work of Richards (1990), Pieterse (1992) and McClintock (1995), Domosh also found that the companies she investigated projected the belief that the west - the United States in this case-was positioned at the top of a hierarchy of civilizations. She has expanded upon their insights by demonstrating that the images of 'foreigners', particularly in Singer and McCormick advertisements, were 'presented as historical actors, as agents of their own transformation, not as simply "frames for the commodity"'(Domosh, 2004, p. 459). Turning towards the present, Domosh (2004, p. 464) also stresses the importance of the historical linkages between late nineteenth and early twentieth century advertising-embedded in ideologies of empire-and current day advertising emerging from neo-liberal discourse grafted onto processes of globalization (Scholte, 2000).

While the explicit use of stereotypes and overt racism are no longer employed by large western companies to sell their commodities and services, an analysis of BWC's marketing is still relevant in relation to contemporary advertising. Today's corporate advertising functions along similar lines by positing a top-down diffusion of knowledge, from the west to the 'rest'; and that without the west's assistance, developing countries will be unable to achieve a similar stage of progress. Ramamurthy (2003, p. 212) notes how, 'modernisation and industrialisation of the third world is presented as only possible by the intervention of European firms passing down their knowledge and expertise'. Like the selling of Tabloid brand medicine chests, many goods are still wrapped up with assumptions of western and white European superiority.

Considering the impact of racial images and a discourse of tropicality in the promotion of Tabloid brand medicine chests, is also relevant towards understanding current day international health and development programmes. Ruth Mayer (2002, p. 1) has traced the transformation of symbolic systems 'from a colonial rhetoric of conquest and discipline to a ... rhetoric of globalization, communication, and control'. For example, in the new rhetoric of globalization, Africa is still commonly referred to, and portrayed, as a diseased and dysfunctional space. In a manner similar to BWC's advertising of Tabloid brand medicine chests, when Africa is discussed in relation to health, it is never simply Africa, but the 'crisis' in Africa, or the 'failure' of Africa (Ferguson, 2006).

Like the studies considered above, this paper has also shown how BWC utilized claims to western and white European superiority, and the belief that Britain was operating at a higher stage of progress compared to its tropical processions. It has expanded on such studies by demonstrating that an analysis of the composition and history of a certain commodity-Tabloid brand medicine chests-complicate such claims, and the relationship between Britain and its tropical colonies. Rather than looking only at how BWC played on and reinforced assumptions of western scientific and white European superiority through the selling of their chests, this paper has shown how such notions 
were inherently problematic and unstable when the history of the commodity itself is investigated.

Overall, this paper has argued that to understand why the chests were advertised and promoted in a manner that attempted to uphold clear distinctions between Britain and its tropical possessions, is intimately related to the political and economic interests of their manufacturer, and the context in which they were sold. Tabloid brand medicine chests and their advertisement were conditioned by history, institutions, science, technology, medicine and culture. As a focal point of analysis, the way in which they were advertised and promoted provides a means of understanding such complex relationships, reminding us not to naturalize the un-natural.

Joanna de Groot (2006, p. 188) has noted how the selling of commodities through popular perceptions of empire and its people was associated with 'relations of power, linking material and political dominance to the making and maintenance of ideas and images'. The medical value of Tabloid brand medicine chests, and the pills they contained, did not simply emerge through an unbiased, natural and empirical process. Rather, their value derived through networks consisting of academic, state and industrial authority in relation to Britain's imperial interests. An analysis of the selling of Tabloid brand medicine chests further reveals how what is considered 'natural' or 'rational' in our daily experience, is, in part, mediated through the objects around us, and the power relationships that determine their meaning.

\section{Acknowledgements}

The author would like to express sincere thanks to Professor Mark Harrison and Dr Rebecca Hodes of the Wellcome Unit for the History of Medicine, University of Oxford, for their comments and insights. The author is also grateful for the referee report's and Les Levidow's valuable comments on previous drafts.

\section{Notes}

${ }^{1}$ For more on imperial expositions and fairs see MacKenzie (1984), Greenhalgh (1988), Coombes (1994) and Hoffenberg (2001).

${ }^{2}$ For some of the more influential arguments on the 'new' imperialism and scramble for Africa see Robinson and Gallagher (1963), Cain and Hopkins (1993), Darwin (1997) and Chamberlain (2001).

${ }^{3}$ Church and Tansey (2007) contend that it was Silas Burroughs, not Henry Wellcome, who initiated the development and production of 'Tabloid' brand medicine chests.

${ }^{4}$ This list was compiled from a description of chest No. 250 in 'Tabloid' : A Brief Medical Guide for Explorers, Missionaries, Travellers, Colonists, Planters and Others (c.1925, pp. 24-30), and cross referenced with Excerpta Therapeutica (1896, pp. 120-123). A comparison of the contents of chest No. 250 from 1896 to the 1920s shows that it contained essentially the same 'Tabloids' and descriptions between this period.

${ }^{5}$ For a discussion of western 'visions' of tropical places and people as more of a negotiation between the west and the 'tropics', rather than a one way Saidean construction by the west, see Driver and Martins (2005).

${ }^{6}$ This statement demonstrates the difference constructed between 'temperate' and 'torrid' zones, and the western belief that climate played a major role in creating a hierarchy of races. There was also considerable debate over the ability of white Europeans to acclimatize and permanently colonize the tropics because of such racialized climatic dichotomies. After the advent of the 'new' tropical medicine, however, many argued that maintaining health in the tropical colonies was simply a matter of protecting against microbial invaders while simultaneously adhering to a moral and racialized regimen regulating diet, drink, sleep, clothing and the 'passions' (Naraindas, 1996). Despite the new epistemological foundations informing British tropical medicine, many physicians and scientists still adhered to environmentalist paradigms 
with a lingering polygenist component, believing permanent colonization of the tropics by white Europeans was impossible. See Kennedy (1990), Livingstone (1999), Anderson (1992), and Harrison (1999).

${ }^{7}$ For discussions of the contested term 'hybridity' see Donald and Rattansi (1992), Young (1995), Modood and Werbner (1997), Spivak (1999) and Pieterse (2004).

${ }^{8}$ Another important study looking at commodities in relation to cultural imperialism and colonial people as consumers is Timothy Burke's (1996) investigation into the marketing of western hygienic products in modern Zimbabwe.

\section{References}

Adas, M. (1989) Machines as the Measure of Men: Science, Technology and Ideologies of Western Dominance (Ithaca: Cornell University Press).

Anderson, W. (1992) Climates of opinion: acclimatization in nineteenth-century France and England, Victorian Studies, 35, pp. 135-137.

Arnold, D. (1996) Inventing topicality, in: David Arnold (Ed.) The Problem of Nature: Environment, Culture, and European Expansion, pp. 141-168 (London: Blackwell).

Arnold, D. (2000) 'Illusory riches': representations of the tropical world, 1840-1950, Singapore Journal of Tropical Geography, 21, pp. 6-18.

Battersby, C. F.H. (1900) Medicine chests, Climate, 2, pp. 26-27.

Bhabha, H. K. (1994) The Location of Culture (London: Routledge).

Brantlinger, P. (1985) Victorians and Africans: the genealogy of the myth of the dark continent, Critical Inquiry, 12, pp. 166-203.

Burke, T. (1996) Lifebuoy Men, Lux Women: Commodification, Consumption, and Cleanliness in Modern Zimbabwe (Durham, NC: Duke University Press).

Burroughs Wellcome \& Co. (BWC) (1896) The Excerpta Therapeutica (London: BWC).

Burroughs Wellcome \& Co. (BWC) (1910) A Brief History of Missionary Enterprise (London: BWC).

Burroughs Wellcome \& Co. (BWC) (1912) The Application of Science to Industry: Souvenir of the Congress of the Universities of the Empire of London (London: BWC).

Burroughs Wellcome \& Co. (BWC) (c.1925) 'Tabloid': Brief Medical Guide for Explorers, Missionaries, Travellers, Colonists, Planters and Others (London: BWC).

Burroughs Wellcome \& Co. (BWC) (1934) The Romance of Exploration and Emergency First Aid from Stanley to Byrd (London: BWC).

Cain, P. J. and Hopkins, A. G. (1993) British Imperialism: Innovation and Expansion, 1688-1914 (Harlow: Longman).

Chamberlain, M. E. (2001) The Scramble for Africa, 2nd edn (London: Addison Wesley Longman).

Chambers, D. W. and Gillespie, R. (2000) Locality in the history of science: colonial science, technoscience and indigenous knowledge, in: Roy MacLeod (Ed.) Osiris, 15, pp. 221-240.

Church, R. and Tansey, E. M. (2007) Burroughs Wellcome \& Co.: Knowledge, Trust, Profit and the Transformation of the British Pharmaceutical Industry, 1880-1940 (London: Crucible Books).

Coombes, A. E. (1994) Reinventing Africa: Museums, Material Culture and Popular Imagination (New Haven: Yale University Press).

Curtin, P. D. (1989) Death by Migration: Europe's Encounter with the Tropical World in the Nineteenth Century (Cambridge: Cambridge University Press).

D'Arcy, P. F. (1999) Laboratory on the Nile: A History of the Wellcome Tropical Research Laboratories (New York: Haworth Press).

Darwin, J. (1997) Imperialism and the Victorians: the dynamics of territorial expansion, English Historical Review, 447, pp. 614-642.

de Groot, J. (2006) Metropolitan desires and colonial connections: reflections on consumption and empire, in: Catherine Hall and Sonya O. Rose (Eds) At Home with the Empire: Metropolitan Culture and the Imperial World, pp. 166-190 (Cambridge: Cambridge University Press).

Domosh, M. (2004) Selling civilization: toward a cultural analysis of America's economic empire in the late nineteenth and early twentieth centuries, Transactions of the Institute of British Geographers, 29, pp. 453-467.

Donald, J. and Rattansi, A. (Eds) (1992) Culture and Difference (London: Sage).

Driver, F. (2001) Geography Militant: Cultures of Exploration and Empire (London: Blackwell). 
Driver, F. and Martins, L. (2005) Tropical Visions in an Age of Empire (Chicago: University of Chicago Press).

Drayton, R. H. (2000) Nature's Government: Science, Imperial Britain and the 'Improvement' of the World (New Haven: Yale University Press).

Fabian, J. (2000) Out of Our Minds: Reason and Madness in the Exploration of Central Africa (Berkeley: University of California Press).

Feierman, S. and Janzen, J. M. (Eds) (1992) The Social Basis of Health and Healing in Africa (Berkeley: University of California Press).

Ferguson, J. (2006) Global Shadows: Africa in the Neoliberal World Order (Durham, NC: Duke University Press).

Greenhalgh, P. (1988) Ephemeral Vista's: The Expositions Universelles, Great Exhibitions, and World's Fairs, 1851-1939 (New York: St. Martin's Press).

Harrison, M. (1999) Climates and Constitutions: Health, Race, Environment and British Imperialism in India, 1600-1850 (Oxford: Oxford University Press).

Havinden, M. and Meredith, D. (1993) Colonialism and Development: Britain and Its Tropical Colonies, 1850-1960 (London: Routledge).

Headrick, D. (1981) The Tools of Empire: Technology and European Imperialism in the Nineteenth Century (Oxford: Oxford University Press).

Hill, J. (2006) Globe-trotting medicine chests: tracing geographies of collecting and pharmaceuticals, Social and Cultural Geography, 7, pp. 365-384.

Hoffenberg, P. H. (2001) An Empire on Display: English, Indian and Australian Exhibitions from the Crystal Palace to the Great War (Berkeley: University of California Press).

James, R. R. (1994) Henry Wellcome (London: Hodder and Staughton).

Kennedy, D. (1990) The perils of the midday sun: climatic anxieties in the colonial tropics, in: John MacKenzie (Ed.) Imperialism and the Natural World, pp. 1-35 (Manchester: Manchester University Press).

Lester, A. (2006) Imperial circuits and networks: geographies of the British Empire, History Compass, 4, pp. $124-141$.

Livingstone, D. N. (1999) Tropical climate and moral hygiene: the anatomy of a Victorian debate, British Journal for the History of Science, 32, pp. 93-110.

Lyons, M. (1992) The Colonial Disease: A Social History of Sleeping Sickness in Northern Zaire, 1900-1940 (Cambridge: Cambridge University Press).

MacKenzie, J. M. (1984) Propaganda and Empire (Manchester: Manchester University Press).

MacLeod, R. (1987) On visiting the 'moving metropolis': reflections on the architecture of imperial science, in: Nathan Reingold and Marc Rothenberg (Eds) Scientific Colonialism: A Cross Cultural Comparison, pp. 217-249 (Washington, DC: Smithsonian Institution Press).

MacLeod, R. (2000) The 'Creed' of Science in Victorian England (London: Aldershot).

Mayer, R. (2002) Artificial Africas: Colonial Images in the Times of Globalization (New Hampshire: The University of New England Press).

McClintock, A. (1995) Imperial Leather: Race, Gender and Sexuality in the Colonial Contest (London: Routledge).

Meade, T. and Walker, M. (Eds) (1991) Science, Medicine, and Cultural Imperialism (London: St. Martin's Press).

Mirzoeff, N. (1999) An Introduction to Visual Culture (London: Routledge).

Modood, T. and Werbner, P. (Eds) (1997) Debating Cultural Hybridity (London: Zed Books).

Naraindas, H. (1996) Poisons, putrescence and the weather: a genealogy of the advent of tropical medicine, Contributions to Indian Sociology, 30, pp. 1-35.

Pieterse, J. N. (1992) White on Black: Images of Africa and Blacks in Western Popular Culture (New Haven: Yale University Press).

Pieterse, J. N. (2004) Globalisation and Culture: Global Mélange (Oxford: Rowman and Littlefield).

Power, H. (1999) Tropical Medicine in the Twentieth Century: A History of the Liverpool School of Tropical Medicine, 1898-1990 (London: Keegan Paul International).

Ramamurthy, A. (2003) Imperial Persuaders: Images of Africans and Asians in British Advertising (Manchester: Manchester University Press).

Richards, T. (1990) The Commodity Culture of Victorian England: Advertising and Spectacle, 1851-1914 (Stanford: Stanford University Press).

Robinson, R. and Gallagher, J. (1963) Africa and the Victorians: The Official Mind of Imperialism (London: MacMillan). 
Ryan, J. (1997) Picturing Empire: Photography and the visualization of the British Empire (Chicago: University of Chicago Press).

Said, E. (1979) Orientalism (New York: Vintage).

Scholte, J. A. (2000) Globalization: A Critical Introduction (Basingstoke: Palgrave).

Spivak, G. (1999) A Critique of Postcolonial Reason (Cambridge, MA: Harvard University Press).

Stepan, N. L. (2001) Picturing Tropical Nature (London: Reaktion Books).

Wilkinson, L. and Hardy, A. (1998) The London School of Hygiene and Public Health: A Twentieth-Century Quest for Global Public Health (London: Keegan Paul International).

Young, A. M. (1994) Antique Medicine Chests: or Glister, Blister \& Purge (London: Vernier Press).

Young, R. J.C. (1995) Colonial Desire: Hybridity in Theory, Culture and Race (London: Routledge). 